Comparative Philosophy Volume 10, No. 1 (2019): 3-17

Open Access / ISSN 2151-6014 / www.comparativephilosophy.org

https://doi.org/10.31979/2151-6014(2019).100105

\title{
APOPHATIC COMMUNITY: YANNARAS ON RELATIONAL BEING
}

\author{
FRED DALLMAYR
}

\begin{abstract}
For Martin Heidegger the story of Western philosophy ended basically in egocentrism or the metaphysics of "subjectivity"; however, he acknowledged the possibility of another path in Greece: that of pre-Socratic thinking. Yet, there is a further path he did not acknowledge: the tradition of Orthodox philosophy and theology. The paper focuses on some key works of the prominent contemporary Greek philosopher Christos Yannaras, for a long time professor in Athens. Taking over the notions of "Being" and ontology, Yannaras construes them (with Heidegger) not as ontic "substances" amenable to epistemic knowledge, but as guideposts to "relational" or participatory experience. His early text On the Absence and Unknowability of God: Heidegger and the Aeropagite explores the (at least partial) affinity between the German thinker and the Orthodox stress on "apophaticism." For Yannaras, apophaticism profoundly reorients philosophical inquiry; it also has important implications for human "personhood" and "freedom." Far from denoting individuation, personhood for him means a face (prosopon) standing out toward others, just as freedom transcends self-will in the direction of a relational event. By way of conclusion, I probe the status of relational "community." For Yannaras, I ask, is community a concretely achieved way of life (exemplified by the Orthodox Church); or does it point more apophatically (and prophetically) to a future advent?
\end{abstract}

Keywords: apophaticism, freedom, modernity, morality, personhood relationality

Martin Heidegger's affection (even predilection) for Greek thought is well known. The dominant theme of his work - the "question of Being"-was ultimately derived from Aristotle, though with an important twist: the transformation of the Greek concept into an existential issue and challenge. To a large extent, it was the conceptual rationalism of classical Greek philosophy which subsequently led Heidegger steadily in the direction of Pre-Socratic thinkers, especially Parmenides, Anaximander, and Heraclitus. In his view, the legacy of the Pre-Socratics was sidelined or forgotten in the history of Western philosophy which, partly under the influence of Plato and Aristotle, developed steadily into the kind of rational-epistemic

DALLMAYR, FRED: Packey J. Dee Professor Emeritus in Political Science and Philosophy, University of Notre Dame, USA. Email: Fred.R.Dallmayr.1@nd.edu 
"metaphysics" which he considered a derailment of thought. Yet, irrespective of thebeneficial or detrimental influence of the Greek tradition, Heidegger throughout his life remained fond of "Griechenland" seen as a homeland of sustained reflection and imagination. As he wrote in a letter of 1957: "Greece remains still the dream which sustains every new initiative of thinking." In 1962, after considerable hesitation and trepidation, Heidegger visited the dream land finally. As he asked in his log-book of the trip: "Can Greece still speak to us in its own language and address us as its hearers - us, people of an age penetrated everywhere by the power and artificiality of technology?",

As Heidegger was surely aware, Greece - if at all able to address us - is bound to speak in different idioms and voices. As it seems, he was not aware of a very contemporary voice which, curiously, manages to reconnect present-day reflection with the world of Heraclitus and the Pre-Socratics: the voice of Greek "orthodox" theology and philosophy. In the present pages, I want to lift up for attention the work of one of the most prominent contemporary Greek thinkers: Christos Yannaras, Professor Emeritus in philosophy at the Pantion University in Athens. Born in 1935, Yannaras studied for some time in Germany-where he encountered the thought of Heidegger - before he turned to additional philosophical and theological studies in Paris and Greece. What attracted Yannaras to Heidegger was chiefly the critique of Western "metaphysics" with its central focuses on rational epistemology and its disdain for experiential knowledge. In a recessed manner, Heidegger's influence is also present in the rejection of Descartes's ego cogito and the embrace of a radical "relationism" on the level of both personal encounters and general ontology. What Yannaras opposes to Western metaphysics is "apophaticism" or an "apophatic faith" which he himself defined as "a stance against knowledge and epistemology," a "denial of 'conceptual idols' and of the psychological props of egocentric selfassurance." Given the great number of his publications I shall focus in the following on a limited number of studies: first, a text dealing explicitly with Heidegger and apophaticism; next, studies devoted to (anti-individualistic) "personalism" and human freedom; finally I shall offer some comments or afterthoughts on "apophatic community."

\section{HEIDEGGER AND THE AREOPAGITE}

As mentioned, Yannaras as a young man studied a few years in Germany where he acquainted himself with Heidegger's writings. The details and scope of his acquaintance are not known (to me). But it is clear that his familiarity extended beyond Being and Time and included some of Heidegger's work after the "Kehre," especially his writings on Nietzsche and "European nihilism." The latter familiarity is evident in one of his earliest texts, published in 1967, titled (in translation) On the

\footnotetext{
${ }^{1}$ Heidegger 1989, 6. The letter of July 16, 1957 was written to Erhart Kästner; see HeideggeR 1986, No. 7.

${ }^{2}$ See Yannaras 2005, 17
} 
Absence and Unknowability of God: Heidegger and the Areopagite. The book opens instantly with a reference to Nietzsche's proclamation of the "death of God" in The Gay Science, put in the mouth of a "madman." For Yannaras, Nietzsche's word does not mean the affirmation or celebration of a straightforward atheism - as it appeared to the madman's hearers in the marketplace. Rather, it denotes the absence or vanishing of a certain "metaphysical" conception of God where the divine is the object of epistemic knowledge. In this sense, he endorses basically Heidegger's interpretation of the proclamation as expounded in his Nietzsche texts in the early 1940's. As he writes: "God is dead' means that the Christian God, the God of Western metaphysics, is but a dead fashioning of the mind, hardly more than a rational idea, an abstract concept. At best, 'God' stands for an idolized, conventional "value'." Since the tenability of this epistemic concept has been shown to be illusory, the place of God in Western thought is now "empty," a marker for divine "absence." Above all, the metaphysical concept is unrelated to human experience and the shaping of Western or European culture. This is what is meant (and what Heidegger meant) by "European nihilism.",

The vanishing of God or the divine from Western thought was not a sudden cataclysmic event; rather, it was the result of a long trajectory moving through several centuries. In Yannaras' portrayal, the denial or absentism of God 'took shape gradually in the West from the fourteenth century onwards, culminating finally in Nietzsche's prophetic proclamation." An important stepping stone was the late medieval, early modern misconstrual of the Greek (both Heraklitian and Aristotelian) notion of reason or "logos," a term that originally still implied a "reference and relation," the means of establishing knowledge "through experienced relationship or the common potentiality of relationship." The departure from this notion of a relational gathering was dramatic. "The Scholastics and Descartes," Yannaras comments briskly," introduced into human history the interpretation of [Greek] logos as [Roman] ratio, and ratio as a self-reliant, subjective capacity, the capacity of individual calculation and reckoning which is competent to define the truth exhaustively." It was from this capacity of calculation that Descartes deduced the concept of a perfect or divine being, a being that ultimately "has the same kind of certainty as a geometrical truth." In line with this deductive process, Yannaras notes, God was either identified with "the concept of an impersonal and abstract 'first cause' (causa prima)" or else as "the absolute authority in ethics (principium autoritatis)." In both cases, God is the figment of the cogito, but unrelated to existential human experience. But seen as a figment or fiction, the concept ultimately was bound to collapse. Thus, "precisely because it offered an absolutized rational affirmation of God. European metaphysics prepared the ground of its own rational refutation."4

Regarding Western efforts to obtain epistemic "knowledge" of the divine, Yannaras reviews the sequence of attempted "proofs" of God-ranging from the Scholastic conception of God as "first cause," to Anselm's "ontological argument," to

\footnotetext{
${ }^{3}$ Yannaras 2005, 21. See also Heidegger 1961 and 1987.

${ }^{4}$ Yannaras 2005, 22-24.
} 
the teleological principle of a necessary "end"-finding all of them flawed as exercises of purely mental acrobatics. The weakness of these exercises was already exposed by the Protestant Reformation when Martin Luther presented God as "inaccessible to reason" and basically "hidden" (Deus absconditus). Although to some extent accepting Luther's verdict, the Enlightenment and critical rationalism preserved the gist of Scholastic efforts by turning God from a substance or essence into a rational postulate or critical ideal. This transformation was accomplished especially by Kant's critical philosophy. In Yannaras' words: "Kant counters the dogmatic conceptual rationalism of Scholastic metaphysics with the critical power of pure reason"- a power which constitutes God as "the ethical demand of the will of the human subject." In this manner, Kant makes the case for "the moral origin of religion, that is, for the understanding of moral principles as divine commands on the basis of a philosophical anthropology." In modified form, this approach was continued by German idealism which brought to fulfillment the formation of a "moralistic anthropological a-theism." This anthropological turn was particularly evident in the work of Fichte who saw the human subject as "the central starting point or axis of any philosophy." While sometimes quarreling with Fichte, other idealists (including Hegel) agreed on the necessary anchoring of knowledge in the consciousness of subjectivity or the "monism of the subject."

Pondering the shipwreck of the epistemic knowledge of the divine, Yannaras turns to the alternative: the "unknowability of God" announced in the book's title, that is, to the apophatic path or approach. As he emphasizes, this approach does not merely involve a denial of knowledge or the simple acceptance of limits of reason in the sense of a "negative theology" (theologia negativa). Such an acceptance was even familiar to Scholasticism as a humble supplement to reason, but denial here was unproductive of new or different insights. In Yannaras words: While diverging from traditional theology, apophaticism appeared first in the West "to demarcate the limits, that is to say, the relativity of cataphatic [positive] affirmation"; however, by merely stressing the limits of reason, this kind inevitably facilitated "the rise of relativism, skepticism, and even agnosticism." Thus, the "via negativia" of the Scholastics ignored or failed to grasp an alternative approach to knowledge and understanding: one that "characterized the entire Greek tradition, both Christian and pre-Christian," namely, knowledge or insight as "the experienced immediacy of relatedness, of the identity of truthfulness and participation." Yannaras at this point introduces the distinction between an "apophaticism of essence" exemplified by Western Scholasticism, and an "apophaticism of the person" characteristic of Christian thought in the Greek East. While the former merely rallied against an epistemic concept, the latter involves a personal experience and discovery: "I start from the discovery that my existence and the knowledge that I have are facts of accomplished relationships - and relationship is not exhausted by conceptual analysis....Thus, if

\footnotetext{
${ }^{5}$ Yannaras 2005, 25-27, 30, 32-34. As Yannaras adds (a bit rashly, 2005, 24): "The logical conclusion of the 'monism of the subject', inflicted on European philosophy by Descartes [and his followers], is not God, but the absolutized subject itself, the 'superman' (Übermensch)."
} 
God exists he is primarily known as a 'person' (hypostasis) in the immediacy of a relationship and not primarily as an 'essence' with its conceptual definition."

This second type of apophaticism, in Yannaras' view, was a distinctive work of Greek thought from the beginning, reaching back to Heraclitus and the Pre-Socratics; it was even present in classical Greek philosophy (which was "distorted" by the Scholastics); but it reached its fullest expression in "orthodox" Christian thought as represented by Gregory Palamas and Dionysios the Areopagite (and his school). In the latter case, the notion of the "unknowability" and "absence" of God implies that God is a non-being or "nothingness"- not in the sense of a simple vacuum but as an inexhaustible source and potentiality. In the words of the Areopagite: "Indeed, the inscrutable One is out of reach of every rational process.... Mind beyond mind, word beyond speech, it is gathered up by no discourse, by no intuition, by no name. It is and it is as no other being is. Source of all beings, it alone could give an authoritative account of what really is." As this teaching was later summarized by Maximos the Confessor: "God is said to be both being and non-being, since he is none of the things that are, but transcends unknowably everything that is; for there is 'nothing' that is known in light of the fact that God is "nothing'." As Yannaras elaborates: "According to the Areopagitical writings, no existential category, not even the 'most spiritual' among the properties of human nature or being can be ascribed to God as determining his essence." Seen in this light, Greek theological apophaticism constitutes "a transcendence of any epistemic methodology-both of the analogical way of affirmation and negation and of the way of causality."7 Yannaras at this point returns to Heidegger, saying: "The 'nihilism' of Heidegger - as a refusal to subject God and Being to conceptual constructs - seems provisionally to fit in with what we have called, relying on the Areopagitical writings, apophatic abandonment." He also cites one of Heidegger's statements: "Atheistic thought that denies the God of philosophy, the God as causa sui, is perhaps closer to the divine God (ist dem göttlichen Gott vielleicht näher)."8

To be sure, Yannaras does not wish to overstate the affinity between Heidegger and the Areopagitical corpus. Apart from the distance of time and culture, there are two features which seem to him to be missing in Heidegger's perspective: the notion of an ontological relation of "persons," and the linkage of apophaticism to human "freedom" and "otherness." As he writes: In the Greek perspective, "there is preserved not only the many-sidedness of the subject's faculty of apprehension, but also the otherness of each subjective approach to knowledge as well as the freedom of approach, the exclusion of any predetermination. In other words, the catholicity of knowing through relationship preserves the chief elements-otherness and freedom - with which we mark out the personal existence of humankind." ${ }^{\text {I }}$ do not

\footnotetext{
${ }^{6}$ Yannaras 2005, 28-29.

${ }^{7}$ Yannaras 2005, 65-67, 69. See also Pseduo-Dionysios, On the Divine Names, 1.1. The statements of Pseudo-Dionysios and Maximos are cited by Yannaras in his 2005, 66-67. On Dionysios, see esp. Louth 2001.

${ }^{8}$ Yannaras 2005, 51, 72. See also Heidegger 1957, 65.

${ }^{9}$ Yannaras 2005, 71.
} 
wish to make too much of this distinction - which seems to be based at least in part on misunderstanding. Thus, the notion of "difference" - as used in Identity and Difference - signifies for Heidegger both a radical distance or "otherness" and simultaneously a mutual belonging or gathering. In turn the concept of "personhood"-borrowed in large part from Max Scheler-is largely preserved in the idea of existential finitude and "singularity" and in the "ekstatic" openness of Dasein to Being. The same openness to Being in its ontological "transcendence" also establishes human "freedom" seen as rupture of empirical determinism. Regarding finally "relationship," no theme is more pervasive in Heidegger's work-provided the term does not designate the artificial joining together of isolated elements.

In the concluding chapters of the discussed text, Yannaras elaborates more fully on the linkage of apophaticism with personhood and personal participation, on the one hand, and with loving "communion," on the other. Distinguishing again between epistemic "essence" and experiential "existence," he writes: "The mode of existence that we know only 'by participation' we call personal. God acts in a personal manner, that is, as a person or rather a community, a trinity of persons." The notion of "person" or "personal" here is closely connected with experiential participation, of the caring inherence of one in the other. This aspect applies also to the experience of the divine: "Hence, we characterize God's mode of existence as personal, primarily because it corresponds to the experience we have of human personal existence: an existence with self-consciousness, with thoughtful relatedness, with 'ekstatic' otherness and the freedom from any predetermination." As one should add: the aspect of participation and experimental relatedness is always marked also by a dimension of "absence and unknowability" which exceeds positive articulation. Hence, experiential participation may be symbolically conveyed, but can "never be exhausted" in positive (cataphatic) formulation.

The same kind of absence or hiddenness is also found in loving or "erotic" relationship where the target of love can never be fully known or possessed-thus always involving an element of "passion" or suffering. The Greek Areopagitical tradition speaks of "eros" as a "yearning" for and "suffering the divine things." In Yannaras' words: apophatic is in this sense "an 'erotic' naming of God, the attribution to God of names, symbols and designations as these emerge from the human erotic relationship with him." Stressing the trans-epistemic quality of apophasis, the same tradition also speaks of the "experience of God as the "mad lover' of the whole creation and of each human person." What this depiction refers to, Yannaras concludes, is "to the precisely ecstatic existence of God, to the erotic will of the Godhead, unapproachable and imparticipable in his essence, to be offered as an active call to personal relationship." 10

\footnotetext{
${ }^{10}$ Yannaras 2005, 84-86, 104-107. As he adds, summing up his findings $(2005,109)$ : "The whole ecclesial life of the Greek East is articulated around the axis and aim of apophatic and erotic knowledge of God. Iconography and hymnology make accessible to the senses this theology of beauty, with the art of referential transition to the 'archetype' of personal immediacy with what is celebrated in icons and hymns." Compare in this context also Yannaras 1991.
} 


\section{PERSON, LOVE, AND FREEDOM}

As mentioned, Yannaras is a prolific scholar, the author of numerous books and other texts. Despite the vast expanse of his writings, however, there is a remarkable continuity and coherence in his outlook; despite ongoing revisions or modifications, there are a number of key themes in his work-some of which had been briefly announced in the study of 1967. How central these themes are to Yannaras' thinking became obvious a few years later, in 1970, when two major works were almost simultaneously published, titled (in translation) Person and Eros and The Freedom of Morality. According to an observer, the publication of the books caused quite a stir, even "an explosion" in intellectual life and established the author as a leading philosopher-cum-theologian in Greece. The first book turned the limelight instantly on the meaning of "person" or "personhood" defining it not as a self-centered identity but as an open or "ekstatic" relationship. Turning to the Greek term for person, "prosópon," Yannaras wrote: "The proposition pros (toward) together with the noun ops (which means 'eye,' 'face,' 'countenance') forms the composite word pros-ópon. I have my face turned toward someone or something, thus indicating a reference or relation." As Andrew Louth (professor of Patristics) elaborates: "A crucial step in the exposition is the analysis of the nature of the 'personal' and the distinction between the 'person' and the 'individual'.... For whereas an individual is defined in terms of his self-identity and distinction from other individuals, as a kind of irreducible unit or monad, person is defined in terms of relationships: an openness to and acknowledgement of the 'other'."11

Yannaras is quite aware of the difficult status of "person" or "personhood" in Western philosophy, especially of its frequent comingling with "consciousness" and "subjectivity." He agrees with Edmund Husserl and much of early phenomenology that consciousness "appears first of all as a necessary and sufficient condition of the phenomenality of phenomena," the fact that phenomena presuppose "the fact of their disclosure" (to consciousness). As Husserl had argued, consciousness is always a "consciousness of something," meaning that consciousness is "intentionally" directed toward a content. For Yannaras, however, this conception still showed a primacy of the subject and awareness as an individual faculty, thus stopping short of grasping "relationality" itself. As he writes (in a Heideggerian vein), "the capacity for consciousness alone is not sufficient to explain the principle of the relation of beings to the person; the former belongs too referential character of the person, but does not explain it." Thus, there is a primacy of "relation" over subjective consciousness, and this primacy is anchored in the "ecstatic" or self-transgressing character of "personhood." For Yannaras, the person is distinguished from an abstract "ego cogito" not only by virtue of its relationality, but also by virtue of its distinctive "personal" quality (what is sometimes called "singularity"). Thus, although a general or universal human feature, personhood is also marked by diversity or difference. As the text emphasizes (again partly following Heidegger): "The starting point of the

${ }^{11}$ Louth, "Introduction” in Yannaras 2005, 7. See also Yannaras 2007, 5; Bradshaw 1973, 205. 
ontological question (the question about Being and beings, their relation and their difference) is not the human power of cognitive reason but the much more basic reality of the person itself." 12

The notion of person or personhood, as articulated by Yannaras, is sharply differentiated from the classical conception of the "rational animal," a being defined by epistemic reason (zoon logon echon). This conception, he acknowledges, was "strongly challenged by Heidegger" who demonstrated that it was "far removed from the core of the ontological problem" and ultimately transferred it to the realm of "value judgments," thus making it the starting point of an "axiological metaphysics." In Yannaras' account, this metaphysics was developed first of all by the Scholastics and later by modern Western rationalism, but was partially overthrown by Immanuel Kant who anchored metaphysics in the critical power of human rationality which, in turn, was anchored in individual "subjectivity." This Kantian approach was modified and refined by German idealist thought_-but not basically contested. Thus, it happened that modern Western thought-for Yannaras-was increasingly characterized "by humanity's imprisonment in subjectivity" and, at the same time, "by the effort to obtain absolute 'objectivity' (through science)," centered in both cases in the individual cogito. At this point, the text invokes again (what it calls) a "great moment" in modern philosophy: namely, the "new ontology of Martin Heidegger," his attempt to formulate "a non-metaphysical ontology," to transcend, via phenomenology, "the absolute and 'ontic' definition of Being, as well as the subjectivity and rationalism of modern metaphyics." Basically, what Heidegger did was to recast the ontological question as "the difference between beings and Being," where the former are disclosed as phenomena, while Being itself "loves to hide," thus hovering between absence and presence. It is the aspect of disclosure and the interplay of absence and presence which renders epistemic certainty in the traditional sense impossible. ${ }^{13}$

An important aspect of Yannaras' notion of personhood is its distinction from a self-enclosed or atomistic individuality, and this via its open-ended relationality. As he writes: "The person, as absolute otherness, is differentiated from anything conceived by the intellect as definable (ontic) being. This is why every person's mode of existence is objectively "indeterminable, unique, dissimilar and unrepeatable." In different words, that which makes a person distinctive- “"to idiazon, his or her otherness" - cannot be epistemically defined but can only be concretely experienced, that is, "as a unique, dissimilar and unrepeatable relation." As one should note, relation here is not understood as the mere joining of pre-existing (ontic) individualities because relation, as a concrete engagement, precedes the possibility of separate existences. The person, Yannaras emphasizes, is "that mode of existence which is actualized as relation, not merely disclosed as relation. It $i s$ only as dynamic reference, only as 'opposite-something', only as unique, dissimilar and unrepeatable relation." Underscoring and further sharpening this point, the text states: "It is

${ }_{12}^{12}$ Yannaras 2007, 6-8.

${ }^{13}$ Op. cit., 9-11. 
evident...that here we are very far from any kind of objectified subjectivism, any kind of axiologically determined priority of the subject as the capacity for consciousness and intellectuality." Proceeding to give to this conception a quasi-ontologically grounding, Yannaras adds: "Whatever is becomes apparent only with reference to a person, is disclosed only within the terms of the relation which reveals the otherness of the person. In other words, person and beings are the term of a relation, and this relation poses [or encapsulates] the ontological question. ${ }^{14}$

As one can see, the traditional ontological question - "what is Being" (and the Being of beings) - is translated here into a question of relationality, and more specifically a relationality of "persons." What is by passed (or at least pushed somewhat into the background) is the question of the relation of Being and non-being and of presence and absence; as a corollary, the so-called "ontic-ontological difference" resurfaces basically as a difference of modes of personhood. It is on the basis of this shift of accent that Yannaras returns to Heidegger's thought, in an effort to reconnect that thought with the Greek religious tradition. A key term in this reconnection is the notion of "ekstasis" or ecstatic openness. In a Heideggerian vein, Yannaras describes his approach as a "transition from the ontic-individual perception of human existence to its ecstatic determination." As he elaborates, however, ekstasis here is not defined as "humanity's ability to 'stand outside' its natural identity, to wonder at its being" (as it was defined by Heidegger). Rather ekstasis now means the "actualization of the person's otherness, that is, the existential presupposition itself of the person." Differently put, ekstasis signifies the transference from the naturally given capacity for thinking to "the otherness of personal actualization." At this point, Yannaras builds a bridge from the self-transcendence of personal existence to the deeper aspirations of Greek Orthodox faith. In his words: "The dynamic and always unachieved consummation of personal relation is the eros of the Greek Church Fathers, the loving impetus and movement of exodus from individualized existence for the sake of the actualization of relation in the highest sense." Eros here means "the dynamics of ekstasy which finds consummation in personal reference to supreme Otherness" (or God). The text here cites the words of Dionysius the Areopagite: "Divine eros is also ekstatic, so that the lovers belong not to themselves but to the beloved as target of love."

As one can see, the issue of "ekstatic" openness is transcribed into a theistic register-although a radically apophatic register. Yannaras returns here to his distinction between the "apophaticism of essence" and the "apophaticism of person," assigning the former basically to the Western tradition and the latter to Eastern or Orthodox thought. Given his emphasis on the centrality of Being-although a Being beyond epistemic definition-Heidegger seems to have placed himself somewhere at the boundary of the two modes of apophaticism (a location also revealed by his concern for non-being or nothingness). Without fully exploring this issue (or leaving

\footnotetext{
${ }^{14}$ Op. cit., 17-19.

${ }^{15}$ Op. cit., 19-20.
} 
it at the margin), ${ }^{16}$ Yannaras in the later part of his study discovers the fullness of sublime relationality in the Christian trinity. In his words: "For the Fathers of the Greek East, the fullness of dimensionless erotic unity is the loving interpenetration of the Persons of the Holy Trinity: God is 'the all of eros'." The Persons of the Trinity are not divided by essence, nor are they separated by power, or place (topos) or energy, since (according to John Damascene) "their abiding in each other and their interpenetration are inseparable." These words are particularly important for the topical placement of the Persons (where Scripture says that the Son "sits on the right hand"). For Yannaras, one has to banish here all spatial delimitation: the place (topos) of God is the "dimensionless personal loving relation, the eros of triadic communion." Differently put: love is the "place" of divine existence. As he adds, this loving relationality percolates from the divine throughout creation and the entire world. In the view of Maximos the Confessor, the whole of creation has to be seen as "a unified dimensionless erotic fact, an erotic relation dynamically arranged in a hierarchy and universal erotic movement which constitutes creation"-always "with reference back to God." In this universal and hierarchical relationality humanity plays a special role as mediator and actualizing agent: "Humanity's role as 'mediator' between God and the world is fulfilled in the dynamic recapitulation of the erotic interdependence of creation. Humanity is the unique potentiality of personal realization of cosmic eros." $" 17$

As a mediator and actualizer of universal relationality, humanity also enjoys the privilege of not being fully tied down to the nexus of cause and effect: the capacity for freedom elevating human beings (potentially) out of the maelstrom of natural necessity. This is the central theme of the companion volume published first in 1970 under the title (in translation) The Freedom of Morality. The book is a paean to human personal freedom achieved (and only achievable) through participation in the cosmic and divinely inspired relationality discussed before. In essence, the book is a critique of and attack on dominant Western theories of morality (from Kant to JeanPaul Sartre): theories where morality is anchored in individual human autonomy and self-determination or else on abstract moral principles or rules (likewise grounded in autonomy). For Yannaras, all these conceptions are vitiated by their egocentrism and their neglect of the "ekstatic" quality of personhood. As he writes, modern Western conceptions tend to leave out of account "the ontological question of the truth and reality of human existence, the question of what 'man' really is as distinct from what he ought to be." What is ignored is that morality is "first and foremost an existential

\footnotetext{
${ }^{16}$ The text contains a longer section on "The Fall and Nothingness," but it does not reach the level of Heideggerian "nihilation." This is evident in passages like the following: "Nothingness constitutes a personal potentiality of existence because it is the denial of the mode of existence which the person alone can attain (or refuse to attain). It is the opposite of Kenosis... Sin is the moral content of nothingness as an existential fact, the measure of the annihilation of existential fulfillment.... Nothingness hence may be defined in the end not as a concept but as a moral reality, a confirmation of the existential truth of the person, the ability of a human being to say No to God-nullifying but not annihilating the truth of his or her personal existence." See Yannaras 2007, 273, 292-293.

${ }^{17}$ Op. cit., 118-122.
} 
event: the dynamic realization of the fullness of human life and existence." For Yannaras, human being is principally a mode of "relationship and communion." This means that the human being is "a person and not an individual, a segment or subdivision of nature as a whole." A person represents not the relation of a part to the whole, but the possibility of summing up the whole in a distinctiveness of relationship, in an act of self-transcendence" (ekstasis). As one needs to note here, self-transcendence is not an individual "project," not an act of willful selfdetermination; rather, it is induced and supported by participation in a divinely ordained cosmic event: Personhood is "the mode of existence shared by God and man; the ethos of trinitarian life imprinted upon the human being." 18

An important point to be taken into account is that personal relationality is not an automatic happening, a simple fact of "nature"; rather it involves an ethical transformation or spiritual "Kehre." Differently put: although relationality prevails as an ever-present potentiality or possibility, its actualization requires cultivation, steady care and "ekstatic" openness. As Yannaras writes: "From the moment when the human person rejects the [spiritual] call and communion in which he himself is grounded, from the moment when he seeks merely natural and existential autonomy, he becomes alienated from himself." The reason is that, left to its own devices, human "nature" is fragmented and divided into "individual wills" expressing the individual's effort to survive in "natural self-sufficiency." Viewed from a properly ontological perspective, however, the "natural" need for individual survival runs counter to "the personal freedom and distinctiveness which can be realized only through love and communion." Thus, human divisiveness and fragmentation are actually a "falling away" from or an "alteration" of the personalist call for relationship. To overcome this alteration requires an effort-guided from above- to loosen the shackles of self-contained individuality and thus to gain genuine freedom: Human beings must refuse to be "wrapped up in the individuality which sets the individual as an ego against the individual existences of other people." This kind of liberation or emancipation is best achieved through spiritual engagement, and especially through attention to the divine "word" which as removed the "gulf between man and God." In Yannaras' word: "This regeneration of 'man' in Christ requires only the cooperation of man's freedom, his assent to Christ's 'frenzied love' for him as a person." As he adds: "It thus becomes clear that the 'morality' of the Gospel is the absolute antithesis of any kind of individual ethics, since it presupposes the transformation of individuality into an existential reality of communion and relationship." 19

\footnotetext{
${ }^{18}$ Yannaras 1996, 14-15, 20-21, 23. As Yannaras observes sternly (114): “Any systematic pursuit of 'improvement' in man through his own individual will and effort, of taming his nature through his own powers, is condemned by nature itself. Man on his own cannot cease to be what he 'naturally' is.... This is also why every anthropocentric, autonomous morality ends up as a fruitless insistence on an utterly inadequate human self-sufficiency, an expression of man's fall."

${ }^{19}$ Op. cit., 30-31, 37, 52-53.
} 


\section{COMMUNITY PAST AND FUTURE}

This stress on "communion" or "community" and the equation of relationship with community prompts me to offer some afterthoughts or critical reflections. As previously indicated, Yannaras has written a great number of books and articles, not all of which can receive attention in a short essay. In lieu of roaming over his larger opus, I consider it preferable to step back and venture a tentative (and surely corrigible) assessment of some of his central thoughts. As it seems to me, a major qualm provoked by his work is the resort to binary opposition, that is, the tendency to slip into the black-and-white rhetoric of radical antithesis. An example is the contrast between individual freedom and the "existential reality" of community or communion. What surfaces behind this contrast is the collision between (Westernstyle) modernity and anti-modernity, where the former term stands for critical reasoning (sapere aude) and the liberation of people from social bondage (including the bondage of a coercive, purely traditional community). Yannaras's texts are vehement in their denunciation of this kind of modernity. As he writes in The Church in Post-Communist Europe, modernity has brought about a way of life that is "antithetical" to and even "diabolically" at odds with the "ecclesial" basis of orthodox life in the East. The separation of Christian faith from society has enabled the growth of a civilization that, in his words, is "barbaric." ${ }^{20}$ Similarly we read in Postmodern Metaphysics: "The modern age signifies a break in all its aspects. Doubtless the matrix of the modern breaks with what was formerly permanent, self-evident and authoritative....The break with established religious tradition and authority defines the aims of the modern age." 21

This emphasis on a break caused by modernity is not confined to Yannaras (and some other defenders of Greek orthodoxy). In different forms, one finds it in most cultures that are victimized (or feel themselves victimized) by modern Western culture and technology. Examples of such cultural backlash can be detected in numerous cultural traditions: in Islam (in the form of Wahhabism and ISIS); in India (in the ideology of Hindutva), and in many other countries (in the upsurge of exclusionary nationalism or chauvinism). ${ }^{22}$ In some of these cases, opposition is virulent and even veers toward aggressive violence. To be sure, Yannaras's work is untarnished by aggressive extremism. Nevertheless, in the confrontation with the modern or contemporary age, his texts often sound harshly dismissive, and certainly do not betray that generous sympathy which, in his own view, should characterize inter-human and inter-cultural relations. To this extent, I tend to agree with Daniel Payne when he depicts Yannaras's work as more nostalgic or backward-looking than forward-looking, more attracted to traditional (now mostly defunct) modes for community life than to contemporary or emerging possibilities. As an alternative to

\footnotetext{
${ }^{20}$ See Yannaras, 2003, 21-30.

${ }^{21}$ Yannaras, 2004, 1-2.

${ }^{22}$ Hostility to Western-style modernity is not limited to foreign or non-Western countries. One can find similar denunciations also in the West. One may recall here the "anti-modernist" doctrine in the Catholic Church in the early part of the last century. Compare also Bloom 1987 and Deneen 2018.
} 
the present situation, he writes, "Yannaras seeks to retrieve the Byzantine autonomous communities that developed toward the end of the Ottoman Empire. The life of these communities was centered around the life of the church or monastery found in its midst.... [Thus] the ecclesial life becomes the basis for human society.... [The community] he is looking for is none other than the Orthodox Church."23

Partly for reasons of inter-cultural sympathy, I tend to shy away from radical breaks or antitheses. Whenever possible I prefer to listen to arguments emphasizing the "dialectic" of cultural developments, and thus also the "dialectic of enlightenment" or the "dialectic of modernity." "What dialectic suggests is that, in history, winnings and losses are closely entwined and that all winnings have losses and via versa. Regarding the issue of modernity one can readily agree with Yannaras about the immense detriments and devastations unleashed by the modern age, evident in the rise of self-centeredness, technological mastery, and dehumanization. However, there are also features which cannot simply be dismissed as losses. Among these features I would count the processes of steadily advancing democratization and also globalization. What these processes bring into now (at least potentially), are novel kinds of "community" which can be embraced from a Christian as well as from broadly spiritual and even secular perspectives. As is well known, modern democracy is largely inspired by the revolutionary motto "liberty, equality, fraternity" - a motto which can be reconciled with Christian aspirations, as Jacques Maritain and others have shown. In the ambiance of the Orthodox tradition, a possible resonance between democracy and Christian faith has also been explored by a number of contemporary thinkers, such as Miroslav Volf. As the latter states, democracy opens up a space where natives and "others" are integrated and where strangers and immigrants can be embraced in the spirit of loving reconciliation and peace. ${ }^{25}$ This quality of openness is further underscored by the process of globalization where people of different cultural backgrounds are brought closer together, thus mitigating and contesting the harsh legacies of racism, ethnocentrism, and xenophobia.

At it seems to me, these new kinds of relationality or community are not (or should not be) too far removed from Yannaras's perspective, especially his accent on the "apophatic" character of all beings and relationships, that is, their not-empiricallyclosed and thus inexhaustible quality. In a judicious and equitable manner, this aspect is fully recognized by Daniel Payne. In his words: "Yannaras's understanding of the human 'person' makes possible the articulation of a manner of existence that necessitates a level of pluralism and difference within [and beyond] society. This is so because, in order to love the other, the other must be different from the self.... Because of the modern situation whereby persons participate in multiple identities, an independent perichoretic participation in the life of the other is enabled by the pluralistic nature of human society [and the world]. In this manner, the person engages [or can engage] in a dialogical relationship with others." This open

\footnotetext{
${ }^{23}$ Payne 2011, 252-253.

${ }^{24}$ The classical text in this domain is Horkheimer and Adorno 1972.

${ }^{25}$ See Volf 1996.
} 
relationality extends also to the church, including the Orthodox Church, in the sense that the church "can function in a pluralistic [democratic] society through dialogue and perichoretic relation with other institutions." Thus, Payne adds, "rather than living a sectarian existence withdrawn from modern society, the church can participate in the lives of modern citizens who seek spiritual answers to existential dilemmas. ${ }^{26}$ In this manner, the judgment of a backward-looking nostalgia for past ways of life is tempered or corrected in favor of present-day relevance. At various points, Yannaras himself has endorsed this correction or change of outlook. In 1986, in a Festschrift for Jürgen Moltmann, Yannaras stated: "Apophaticism means the refusal to exhaust knowledge of the truth in its formulation"-which also means "its past or traditional formulation." The title of the Festschrift was God's Future-Future of the World. Thus, in his contribution Yannaras clearly recognized the "futurism," that is, the promised advent of the "kingdom to come."27

\section{ACKNOWLEDGEMENTS}

I would like to thank the journal's referees for their professional review of this paper.

\section{REFERENCES}

Bloom, Allan (1987), The Closing of the American Mind (New York: Simon and Schuster).

Bradshaw, Malcolm (1973), "Review", in Eastern Churches Review 5: 202-210.

Dallmayr, Fred (2017), Democracy to Come: Politics as Relational Praxis (New York: Oxford University Press).

Dallmayr, Fred (2018), Gemeinschaft und Differenz: Wege in die Zukunft (Freiburg: Verlag Karl Alber).

Deneen, Patrick (2018), Why Liberalism Failed (New Haven: Yale University Press).

Deuser, Hermann et al. (eds) (1986), Gottes Zukunft-Zukunft der Welt: Festschrift für Jürgen Moltmann zum 60. Geburtstag (Munich: Kaiser Verlag).

Heidegger, Martin (1957), Identität und Differenz (Pfullingen: Neske).

- (1961), "Der Europäische Nihilismus", in Nietzsche vol. 2. (Pfullingen: Neske), 31-256.

- (1986), Martin Heidegger-Erhart Kästner Briefwechsel (1986). H. W. Petzet, editor (Frankfurt-Main: Klostermann).

- (1987), "European Nihilism", in David F. Krell (ed.), Nietzsche, Nihilism, vol. 4 (San Francisco: Harper \& Row), 3-250.

- (1989), Aufenthalte (Frankfurt-Main: Klostermann).

Horkheimer, Max and Theodor W. Adorno (1972), Dialectic of Enlightenment, trans. John Cummings (New York: Seabury Press).

Louth, Andrew (2001), Denys the Aeropagite (London: Continuum).

${ }^{26}$ Payne 2011, 263. Compare also my "Rule of, by and for the People: For an Apophatic Democracy," in my 2017, 22-41, and my 2018.

${ }^{27}$ Yannaras 1986, 374. 
Payne, Daniel P. (2011), The Revival of Political Hesychasm in Contemporary Orthodox Thought: The Political Hesychasm of John S. Romanides and Christos Yannaras (Lanham, MD: Lexington Books).

Volf, Miroslav (1996), Exclusion and Embrace: A Theological Exploration of Identity, Otherness and Reconciliation (Nashville, TN: Abingdon Press).

Yannaras, Christos (1986), "Apophatik und politisches Handeln", in Hermann Deuser et al., Gottes Zukunft-Zukunft de Welt (Munich: Kasier Verlag), 372-376.

- (1991), Elements of Faith: An Introduction to Orthodox Theology, trans. Keith Schram (Edinburgh, Scotland: T \& T Clark).

- (1996), The Freedom of Morality, trans. Elizabeth Briere (Chestwood, NY: St. Valdimir's Seminary Press).

- (2003), The Church in Post-Communist Europe (Berkeley, CA: Inter-Orthodox Press).

- (2004), Postmodern Metaphysics, trans. Norman Russell (Brookline, MA: Holy Cross Orthodox Press).

- (2005), On the Absence and Unknowability of God: Heidegger and the Aeropagite, trans. Hazalamtos Ventis (London-New York: T \& T International).

- (2007), Person and Eros, trans. Norman Russell (Brookline, MA: Holy Cross Orthodox Press). 